MOVERS

\section{David Bentley, chief scientist, Solexa, Chesterford, UK}

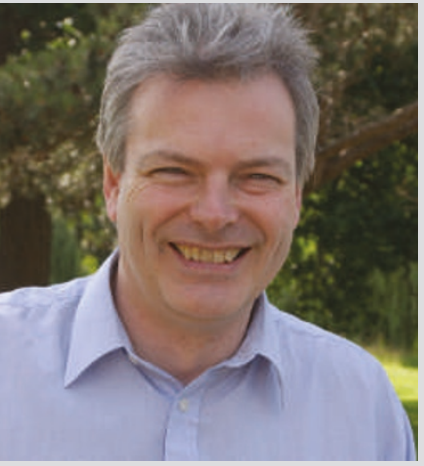

1993-2005: Head of human genetics and principal investigator, Wellcome Trust Sanger Institute, Hinxton, UK 1991-93: Senior lecturer, United Medical and Dental Schools of Guy's and St Thomas's Hospitals, London 1988-91: Lecturer, United Medical and Dental Schools, London

When David Bentley was in his early teens, he was already nurturing his fascination with molecular biology. It was not yet being taught in schools, so he learned about life at the molecular level at home with his mother, a biology teacher who shared his interest. Together, they were often up late at night reading, among other things, the early monographs on the structure of DNA.

This childhood excitement - and later, encounters with pioneering geneticists such as John Sulston - were the starting points for a career spent at the forefront of major advances in human genetics. With a PhD in molecular biology, Bentley was a postdoctoral fellow at Guy's and St Thomas's Hospital in London, studying the mutations that cause genetic diseases such as haemophilia. Drawn into the small but growing community of geneticists, he began meeting Sulston, who became an important mentor. It was he who invited Bentley to be a founding member of the Sanger Centre (now the Wellcome Trust Sanger Institute) near Cambridge, UK, one of the world's top genome centres and a major player in the Human Genome Project.

While at the Sanger, Bentley met two lecturers in the chemistry department of the University of Cambridge as they were founding their company, Solexa. He was captivated by their vision for a new kind of DNA technology: anchoring millions of single DNA molecules on a chip for simple, fast, cheap DNA sequencing and analysis. "It swept away so many problems that we had to deal with every day in the lab," says Bentley. He joined the new company's advisory board.

About four years ago, Bentley was tempted to join the company full-time, but decided to stay at the Sanger because he was starting new genetics projects there. He continued to be an adviser to Solexa as it moved towards its goal of building an instrument that can sequence an entire human genome at a fraction of today's costs. Over the past year and a half, it became clear that the technology was beginning to work, says Bentley, and he wanted to devote more time to applying it to human genetics.

Bentley is now moving to Solexa as chief scientist, which in many ways is sending him back to his early days in molecular biology. "It's refreshing to return to my roots," says Bentley. He doesn't see this as abandoning academia in favour of industry. "I see a coming together of academia and industry, not a split," says Bentley. "It's possible to bring an academic ethos to a commercial setting and to bring a commercial ethos to an academic setting."

Corie Lok
SCIENTISTS \& SOCIETIES

\section{An academy of their own}

No time in a scientific career feels

Ionelier than the limbo reserved for postdocs on the bumpy road to tenure. This is particularly true in Germany, with its hierarchy that segregates the tenured 'haves' from the 'have-nots'.

The Young Academy, founded in 2000, each year brings ten young scientists out of this isolation. A joint venture of the Berlin-Brandenburg Academy of Sciences and the Leopoldina Society, it is funded by the German education and research ministry. Membership is for five years and is open to any German academic who has received a $\mathrm{PhD}$ in the previous three to seven years; selection aims to be purely merit-based. Members receive some grant money but are not guaranteed positions. The goals are modest: interdisciplinary exchange, outreach to society, and giving young scientists a unified voice. Yet, after five years, the results have been unique.

At a time when top-down reforms in European higher education and research are politically driven, the Young Academy stands out as a fruitful grassroots approach to bringing scientists from disparate fields together. Our activities have included launching the first large-scale study of the effects of Germany's reformed tenure system on career development and interdisciplinary projects involving, for example, neuroscientists

psychologists and philosophers.

Implementing these activities was often laborious, but for many members, this was the first chance to interact with scientists outside our own fields. For me as a physicist, exposure to the conceptual sophistication of the humanities was an education in precision beyond formulae. I revelled in learning first-hand about current malaria research and the workings of bee vision; as a young scientist, I felt my voice was heard.

The Young Academy is too new and reaches too far beyond disciplinary borders to help much with individual career advancement. But its real raison d'être ranges beyond job opportunities: to help young scientists develop a fuller view of the scientific universe; to give this view human meaning by associating it with faces and friends; to remind them that science is an endeavour of freely organized minds; and to urge them to take this spirit to the scientific community at large. I recommend other countries to follow this example. Young academies may be a way to give the old idea of scientific academies a second lease of life. Ulrich Schollwöck is a professor of theoretical physics at RWTH Aachen University. He is a founding member and former president of the Young Academy.

\section{GRADUATE JOURNAL}

\section{Eye-opening meeting}

Sometimes we do not realize how much we benefit from seemingly insignificant events. I recently attended a conference where I presented a poster. At first, I didn't think this conference would be anything special; just part of the ordinary life of every scientist. But going to it turned out to be a really good decision. I met several interesting scientists who became interested in my project. I received a lot of useful feedback on this work, which was of great value given the significant number of specialists from the field there. I learned some new techniques. And I realized how misguided my doubts about coming had been. Attending the conference was important for me, not only scientifically but also socially. I went with some colleagues from the institute where I work. I cannot imagine a better opportunity to get to know your co-workers as real people than at a conference. Suddenly you see certain features that you would not observe in any other situation: you can see who are the true professionals. I also made friends with young scientists from the United States and from some other European countries. We discussed how we could work together and share information to improve our skills. The conference was indeed a useful experience for me, especially as I am new in the field and am just starting to build my career. I will attend this kind of event more often. Karolina Tkaczuk is a graduate student at the Technical University of Lodz, Poland. 